\section{Blood Components of Range Cattle: Phosphorus, Calcium, Hemoglobin, and Hematocrit $^{1}$}

\author{
W. G. KIRK AND GEORGE K. DAVIS \\ Animal Scientist Emeritus, Range Cattle Experiment Station, Ona; and \\ Animal Nutritionist, Animal Science Department, \\ University of Florida, Gainesuille.
}

\section{Highlight}

Individual blood samples showed variation in components between range cows and for the same animal at different seasons. Adjusted means values for all blood samples were: phosphorus and calcium per $100 \mathrm{ml}$ plasma 5.2 and $11.4 \mathrm{mg}$, respectively; hemoglobin $11.6 \mathrm{gm}$ per $100 \mathrm{ml}$ blood; and hematocrit $54 \%$ packed cells. Blood calcium, hemoglobin, and hematocrit levels were significantly influenced by scason and brecd of cow. There was a highly significant season effect on blood phosphorus, a significant breed $X$ season interaction, and a non-significant effect when values were averaged for all seasons.

The relationship between pasture and animal performance is of particular interest when cattle are grazed on improved or native pastures. The composition of the pasture at different periods during the year establishes the base supply of nutrients which must meet the animal nutritional requirements.

Unburned wiregrass (Aristida spp.) from phosphorus (P)-deficient areas (Becker et al., 1933) contained an average of $0.038 \%$ and from burned ranges $0.082 \%$ phosphorus while wiregrass from burned healthy ranges had $0.135 \%$. Unpublished data from the Range Cattle Experiment Station (RCES) show that nine samples of grass harvested in a 12-month period from an area protected from burning averaged $0.07 \%$ phosphorus and $0.43 \%$ calcium. Nine samples from an adjoining area which was burned in the spring had $0.09 \%$ phosphorus and $0.52 \%$ calcium. According to Cunha et al. (1964) unburned wiregrass may furnish less than onethird and a burned area slightly more than one-third of the total phosphorus requirements of a nursing cow. Duncan and Epps (1958)

\footnotetext{
${ }^{1}$ University of Florida Institute of Food and Agricultural Sciences, Journal Article No. 3184. Received February 19, 1969; accepted for publication January 8, 1970.
}

reported that to meet the requirements for a nursing cow the minimum phosphorus in air-dried forage was $0.18 \%$, while the National Research Council (1963) suggests that $0.15 \%$ meets the need of all but fattening cattle. In Florida Cunha et al. (1964) reported that inorganic phosphorus below $5 \mathrm{mg}$ per $100 \mathrm{ml}$ blood plasma is reason to suspect a deficiency.

Blood was obtained at five periods in a year from five groups of grazing cows wintered under different management practices to ascertain phosphorus, calcium, hemoglobin, and hematocrit values.

The present blood component study was imposed on cow-calf herds grazing unimproved Florida flatwoods and fed different supplements during winter. The pasture area consisted mainly of Immokalee and Leon soil types with numerous small ponds, typical of large areas in central and south Florida. Wiregrass predominated on the flatwoods and there were some broadleafed grasses, many saw palmettos (Serenoa repens (Bartr.) Small) and a few pine trees.

\section{Methods}

The 800-acre area was divided into five pastures of 160 acres each. Forty-six native and grade Brahman, Devon, and Hereford cows from 7 to 14 years of age were main- tained on the area. They were separated into two lots of eight and three lots of 10 animals for the winter supplement period. The 46 cows ran together from March 22 to November 22, being rotated on the five fields. Treatment of pasture and average daily supplement fed per animal from November 22 , 1944, to March 21, 1945, 119 days, were as follows:

Lot 1.8 cows, pasture not burned. Lot 2.8 cows, $1 / 2$ pasture burned.

Lot 3.10 cows, $1 / 2$ pasture burned plus 6.6 pounds cane molasses daily.

Lot 4.10 cows, $1 / 2$ pasture burned plus 7.3 pounds fresh sugar can daily.

Lot 5.10 cows, $1 / 2$ pasture burned plus 1.3 pounds $41 \%$ protein cottonseed pellets daily.

One-quarter of cach pasture for Lots 2, 3, 4, and 5 was burned in late November and an additional $1 / 4$ of these same pastures was burned the following January. The mineral, described by Becker et al. (1957), to which the cattle had access consisted of $58 \%$ defluorinated phosphate, $33.89 \%$ common salt, $3.39 \%$ red oxide of iron, $0.68 \%$ copper sulfate, $0.04 \%$ cobalt chloride, $2 \%$ cane molasses, and $2 \%$ cottonseed meal.

A $25 \mathrm{ml}$ sample of blood from cows in the five herds was obtained on December 11, 1944 and on January 31, April 4, August 21, and October 16 in 1945. Samples were citrated and chilled with crushed ice until analyzed. Phosphorus in blood plasma was determined by the molybdophosphoric acid colorimetric method of Fiske and Subbarow (1925); calcium in plasma by the titrimetric permanganate procedure of Clark and Collip (1925); hemoglobin by the acid hematin colorimetric technique of Cohen and Smith (1919); and hematocrit by centrifuging the citrated blood at 1860 times gravity (Relative Centrifugal Force) for 30 minutes in calibrated tubes. 


\section{Results and Discussion}

\section{Statistical Analysis}

The least square analysis of variance $^{2}$ (Table 1) showed that blood hemoglobin, blood hematocrit, and blood calcium levels were significantly influenced by season and breed of cow. There were no significant changes in rank of the different breeds from season to season as indicated by the non-significant

${ }^{2}$ Statistical analyses by Frank G. Martin, Associate Statistician and Marvin Koger, Animal Geneticist, IFAS, University of Florida, Gainesville. breed $\times$ season interaction for these blood constitutents. There was a highly significant effect of season on blood phosphorus, no significant average breed effect, but a significant change in rank of breeds from one collection date to another.

The adjusted means and range in values of blood components for the four breeds are given in Table 2. The pattern of the breed differences (Kramer 1957) show that the level of hemoglobin and hematocrit were higher in the Brahman (Bos indicus) than in the other three breeds $(\mathrm{P}<.01)$ with no significant differ-

Table 1. Analysis of variance mean squares.

\begin{tabular}{|c|c|c|c|c|c|c|c|c|}
\hline \multirow[b]{2}{*}{ Source } & \multicolumn{2}{|c|}{ Hemoglobin } & \multicolumn{2}{|c|}{ Hematocrit } & \multicolumn{2}{|c|}{ Phosphorus } & \multicolumn{2}{|c|}{ Calcium } \\
\hline & $\mathrm{df}$ & M.Sq. & $\mathrm{df}$ & M.Sq. & df & M.Sq. & $\mathrm{df}$ & M.Sq. \\
\hline Season & 4 & $35.8284 * *$ & 4 & $741.8364^{* *}$ & 4 & $12.5435 * *$ & 3 & $21.3716^{* * *}$ \\
\hline Breed & 3 & $52.4064^{* *}$ & 3 & $1314.4955^{* *}$ & 3 & 1.4430 & 3 & $2.5458^{*}$ \\
\hline $\begin{array}{c}\text { Season } x \\
\text { Brced }\end{array}$ & 12 & 2.9459 & 12 & 65.3480 & 12 & $1.6667 *$ & 9 & 0.6218 \\
\hline Error & 175 & 2.6816 & 170 & 61.1902 & 165 & 0.7681 & 128 & 0.8830 \\
\hline
\end{tabular}

* Significant at the $5 \%$ level.

** Significant at the $1 \%$ level.

Table 2. Breed groups and adjusted means for blood components.

\begin{tabular}{|c|c|c|c|c|c|}
\hline \multirow{2}{*}{$\begin{array}{c}\text { Blood } \\
\text { constituents }\end{array}$} & \multicolumn{4}{|c|}{ Breed } & \multirow{2}{*}{$\begin{array}{c}\text { Adjusted } \\
\text { means } \\
\text { values1 }\end{array}$} \\
\hline & Native & Devon & Hereford & Brahman & \\
\hline \multicolumn{6}{|c|}{ Inorganic phosphorus (mg/100 ml plasma) } \\
\hline Adjusted means & 5.0 & 5.0 & 5.3 & 5.3 & $\begin{array}{c}5.2 \\
(187)\end{array}$ \\
\hline \multirow{2}{*}{$\begin{array}{ll}\text { Range: low } & \text { high }\end{array}$} & 3.1 & 2.9 & 3.0 & 3.7 & - \\
\hline & 8.9 & 7.8 & 7.8 & 7.5 & - \\
\hline \multicolumn{6}{|c|}{ Calcium (mg/100 ml plasma) } \\
\hline Adjusted means & 10.9 & 11.1 & 11.3 & 11.8 & $\begin{array}{r}11.4 \\
(144)^{2}\end{array}$ \\
\hline \multirow{2}{*}{$\begin{aligned} & \text { Range: low } \\
& \text { high }\end{aligned}$} & 9.0 & 8.2 & 8.3 & 9.8 & - \\
\hline & 14.3 & 14.4 & 13.9 & 13.9 & 一 \\
\hline \multicolumn{6}{|c|}{ Hemoglobin (gm/100 $\mathrm{ml}$ blood) } \\
\hline Adjusted means & 11.3 & 10.9 & 11.4 & 12.7 & $\begin{array}{l}11.6 \\
(195)\end{array}$ \\
\hline \multirow{2}{*}{$\begin{array}{ll}\text { Range: } & \text { low } \\
& \text { high }\end{array}$} & 9.2 & 6.4 & 7.2 & 10.8 & - \\
\hline & 14.9 & 16.0 & 15.3 & 16.1 & 一 \\
\hline \multicolumn{6}{|c|}{ Hematocrit (\% packed cells) } \\
\hline Adjusted means & 53.9 & 50.6 & 52.9 & 58.9 & $\begin{array}{l}53.5 \\
(191)\end{array}$ \\
\hline \multirow{2}{*}{ Range: $\begin{array}{l}\text { low } \\
\text { high }\end{array}$} & 36.7 & 31.3 & 36.7 & 41.8 & - \\
\hline & 67.8 & 68.4 & 68.4 & 85.0 & - \\
\hline
\end{tabular}

1 No. blood samples in brackets.

2 No. determination on samples taken April 4, 1945. ence among the native and Devon and Hereford (Bos tarus) breeds. Brahman cows had higher blood calcium than the native and Devon groups $(\mathrm{P}<.01)$ with the difference between Brahman and Herefords being nonsignificant. Method of handling and disposition of animals may affect the quantitative value of some blood components.

The breed and season subclass means for blood phosphorus (Table 3) show the changes in rank which were responsible for the significant breed $\times$ season interaction for this constituent. The interpretation of this interaction is uncertain. It is recognized, however, that phosphorus levels are influenced by pregnancy, lactation status, and level of milk production. It is probable that these factors were responsible for breed-phosphorus differences being inconsistent from one collection period to the next. Breed differences in blood phosphorus were small and nonsignificant when averaged over all five seasons.

\section{Phosphorus}

Data in Table 2 show that inorganic phosphorus blood values for the five groups of cows were normal averaging $5.2 \mathrm{mg}$ per 100 $\mathrm{ml}$ plasma. Individual cows, however, had values below $4.0 \mathrm{mg}$ per $100 \mathrm{ml}$ plasma, close to the minimal amount considered adequate to meet cattle requirements. A Devon cow, in Lot 2 ( $1 / 2$ of range burned) had a value of $2.9 \mathrm{mg}$ on January 31 , 10 days after calving; in April, 4.5 mg; August, $3.4 \mathrm{mg}$; and in October, $6.8 \mathrm{mg}$. Budyka (1964) found phosphorus blood plasma values of $8.9 \mathrm{mg}$ for cows in late gestation compared to $3.8 \mathrm{mg}$ immediately after delivery. There was little difference in average blood phosphorus in December, January and April, being $5.1 \mathrm{mg}, 5.2 \mathrm{mg}$, and $5.1 \mathrm{mg}$, respectively, while values were lowest in August, $4.3 \mathrm{mg}$, and highest in October, $6.0 \mathrm{mg}$. Sixty percent of the blood values were between 4.0 and $6.0 \mathrm{mg}$ per $100 \mathrm{ml}$ plasma, $17 \%$ blood values in the P-deficiency range, below $4.0 \mathrm{mg}$, 
Table 3. Adjusted means for blood phosphorus by season and breed.

\begin{tabular}{lcccc}
\hline \hline \multirow{2}{*}{$\begin{array}{c}\text { Collection } \\
\text { date }\end{array}$} & \multicolumn{4}{c}{ Phosphorus $\times$ scason intcraction } \\
\cline { 2 - 5 } & Native & Devon & Hereford & Brahman \\
\hline Dec. 11, 1944 & 4.8 & 5.0 & 5.1 & 5.1 \\
Jan. 31, 1945 & 6.4 & 5.1 & 5.6 & 4.9 \\
Apr. 4, 1945 & 4.3 & 5.0 & 5.3 & 5.9 \\
Aug. 21, 1945 & 3.4 & 4.1 & 4.6 & 5.0 \\
Oct. 16, 1945 & 6.0 & 6.1 & 6.0 & 5.7 \\
Adjusted mean & 5.0 & 5.0 & 5.3 & 5.3 \\
\hline
\end{tabular}

and $23 \%$ above $6 \mathrm{mg}$ phosphorus. Duvall and Hansard (1967) reported average values of $5.8,6.1$, and $6.4 \mathrm{mg}$ phosphorus per $100 \mathrm{ml}$ plasma in Louisiana range cattle during April, early September, and November, respectively. Shirley et al. (1968) found that cows grazing pangolagrass without phosphorus fertilizer had 4.3, compared to 5.1 mg phosphorus per $100 \mathrm{ml}$ plasma for cows on phosphated pastures.

\section{Calcium}

Calcium values for all herds were the lowest $(9.6 \mathrm{mg}$ per $100 \mathrm{ml}$ plasma) during December and the highest $(12.3 \mathrm{mg})$ during April. There was no shortage of calcium since the native forage had from 0.4 to $0.5 \%$ and cattle consumed an estimated 23 pounds of calcium yearly from the feed plus that in the complete mineral eaten. The values suggest that blood calcium increase reflected changed grazing conditions on spring pasture as compared with winter pasture. Duvall and IIansard (1967) observed higher average values of $13.9,13.6$, and $12.8 \mathrm{mg}$ calcium per $100 \mathrm{ml}$ plasma in April, early September, and November, respectively, in range cattle in Louisiana. Their values were higher and less variable than those obtained in this study. There were no clinical symptoms of calcium deficiency with any of the cows. Calcium values obtained by Shirley et al. (1968) for cows grazing pangolagrass as the only source of this element averaged 9.8, $10.5,11.3$, and $10.4 \mathrm{mg}$ per $100 \mathrm{ml}$ plasma in March, June, September, and December, respectively. components.

\section{Hemoglobin}

Hemoglobin blood values averaged $10.6,10.4,12.5,11.8$, and 12.8 $\mathrm{gm}$ per $100 \mathrm{ml}$ blood in December, January, April, August, and October, respectively. Pasture forage had its highest nutritional value in $\Lambda$ pril. The Octobcr blood collection date was after the calves were weaned. These two factors may have influenced the higher hemoglobin values for these seasons. Hemoglobin value of $11.6 \%$ was considered above the average for cows grazing unimproved pasture in Florida (unpublished data) on the basis of several hundred samples taken over more than 20 years. Brooks and Hughes (1932) reported values of $11.7 \pm 0.1$, and $10.9 \pm 0.1$ gm for 59 heifers and 103 cows, respectively, of dairy breeds in New York. Duvall and Hansard (1967) found 33 range cows in Louisiana to average $11.6 \pm 0.1,12.7 \pm 0.2$, and $13.8 \pm 0.2 \mathrm{gm}$ in April, early September and November, respec- tively. Hemoglobin values for cows on improved pasture obtained by Shirley et al. (1968) ranged from 12 gm per $100 \mathrm{ml}$ blood in March to $13.2 \mathrm{gm}$ in December.

\section{Hematocrit}

Hematocrit valucs for Brahmans were $24 \%$ greater than for Devons, which breed group had the lowest value for this blood constituent. One Brahman cow had hematocrit values of $70.2,85.0,45.0,59.5$, and $62.7 \%$ packed cells in the five collection months while a cow of similar breeding had 41.8, 52.7, 58.7, 53.3, and $47.9 \%$ during the same periods. A single blood sample may reflect a temporary acute situation rather than long term effects.

Average hematocrit values were $57,58,47,55$, and $52 \%$ packed cells for December, January, April, August, and October, respectively. Birth of calves and the improvement in quality of pasture from March to June may have influenced blood cell volume. These factors, however, do not explain the variation in hematocrit values for individual cows in all lots, or the wide range of 31.1 to $85.0 \%$ in Lot 1 . The low individual hematocrit values for the five lots ranged from 31.1 to $41.8 \%$ and the high values from 67.8 to $85.0 \%$. Braun (1946) found that hematocrit values for cows 18 to 30 months of age were $34.4 \pm 0.6 \%$ while Shirley et al. (1968) obtained average values from 48.2 to $52.1 \%$ for different groups of cows on improved pasture.

Table 4. Effect of pasture management and supplements fed on blood

\begin{tabular}{|c|c|c|c|c|c|}
\hline $\begin{array}{l}\text { Pasture } \\
\text { treatment }\end{array}$ & Supplement & $\begin{array}{c}\text { Phosphorus } \\
\text { (mg/100 ml } \\
\text { plasma) }\end{array}$ & $\begin{array}{c}\text { Calcium } \\
(\mathrm{mg} / 100 \mathrm{ml} \\
\text { plasma })\end{array}$ & $\begin{array}{c}\text { Hemoglobin } \\
(\mathrm{gm} / \mathrm{l00} \mathrm{ml} \\
\text { blood })\end{array}$ & $\begin{array}{l}\text { Hematocrit } \\
\text { (\% packed } \\
\text { cells })\end{array}$ \\
\hline No burning & None & 5.0 & 11.0 & 11.6 & 52.0 \\
\hline $1 / 2$ burned & None & 4.8 & 11.1 & 12.1 & 55.0 \\
\hline $1 / 2$ burned & $\begin{array}{l}\text { cane } \\
\text { molasses }\end{array}$ & 5.2 & 11.4 & 11.1 & 51.0 \\
\hline $1 / 2$ burned & $\begin{array}{l}\text { fresh } \\
\quad \text { sugarcane }\end{array}$ & 5.3 & 11.2 & 11.8 & 57.0 \\
\hline $1 / 2$ burned & $\begin{array}{l}\text { cottonseed } \\
\text { pellets }\end{array}$ & 5.4 & 11.5 & 11.1 & 51.0 \\
\hline Average & & 5.2 & 11.4 & 11.6 & 53.5 \\
\hline
\end{tabular}


Pasture Management and Supplement Feeding

The effect of management and supplement feeding on the four blood components are shown in Table 4. Burning $1 / 2$ the pasture resulted in the lowest average blood phosphorus and highest hemoglobin values. Burning pasture plus feeding cane molasses gave the lowest average hemoglobin and hematocrit values and feeding fresh sugarcane gave the highest values for hematocrit.

The 46 cows had a $67 \%$ weaned calf crop in 1945. Calf production per cow ranged from 180 pounds for the herd on unburned pasture to 234 pounds when $1 / 2$ pasture was burned and reached 256 pounds when $1 / 2$ pasture was burned plus feeding 1.3 pounds of cottonseed pellets daily per cow.

Burning of pasture and supplement feed increased calf production per cow but did not affect phosphorus, calcium, hemoglobin, and hematocrit blood levels. Pregnancy, parturition, lactation, weaning of calves, and nutritive quality of pastures appeared to have a greater influence on blood components than did pasture management and winter feeding.

\section{Mineral Consumption}

Average mineral consumed per cow in the 119-day winter period beginning on November 22, 1944 , was: Lot 1, unburned pasture, 25 pounds; Lot 2, $1 / 2$ pasture burned, 21 pounds; Lot 3, 1/2 pasture burned and fed cane molasses in winter, 19 pounds; Lot 4, 1/2 pasture burned and fed fresh sugarcane, 20 pounds; Lot 5, 1/2 pasture burned and fed cottonseed pellets, 19 pounds. Cows in Lot 1 eating an average of 59 pounds of mineral yearly, $(25$ pounds during the winter and 34 pounds when the 46 cows were together during the remainder of the year) obtained 5.1 pounds of phosphorus. This amount plus that estimated to be in range forage eaten gave a total of 8.1 pounds phosphorus. This is calculated to be equivalent to $0.16 \% \mathrm{P}$ in the ration on an air-dry basis and is

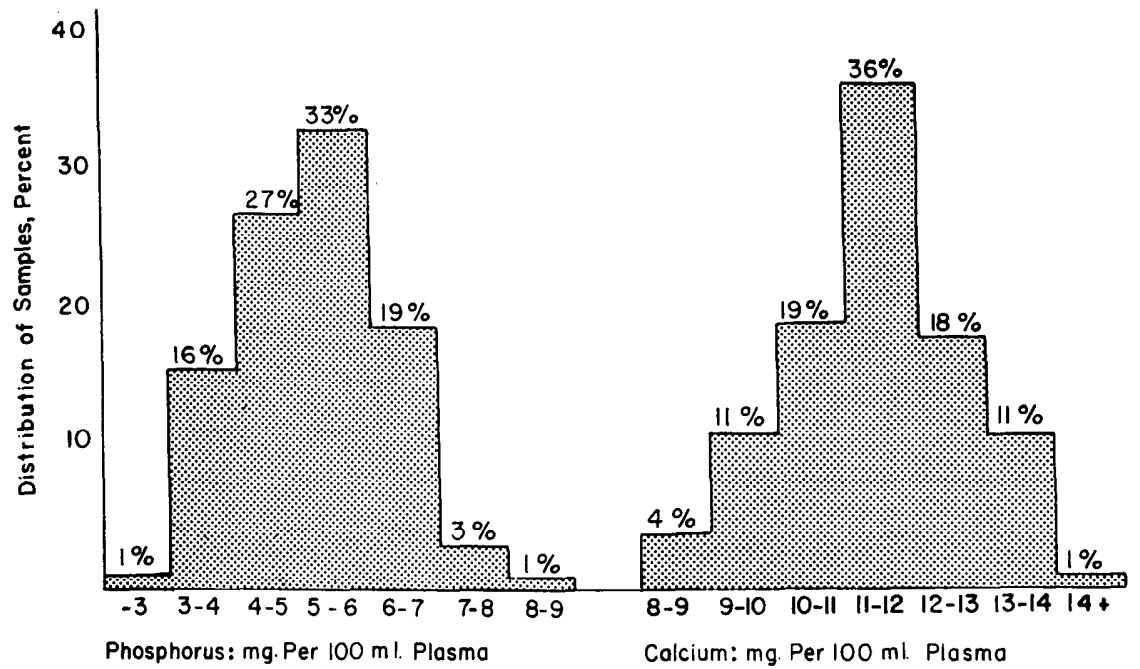

Fig. 1. Distribution of phosphorus and calcium in cows blood.

slightly below the minimum requirements for a beef cow.

Becker et al. (1965) showed that iron, copper, and cobalt were essential to the well being of cattle. Cows in the present study on unburned range during the winter (Lot 1) consumed an average of 59 pounds of complete mineral a year which contained 20.0 pounds common salt, 2.00 pounds red oxide of iron, 0.40 pounds copper sulfate, and 0.02 pounds cobalt chloride. These elements plus those obtained from the forage eaten was considered adequate to maintain blood hemoglobin values.

\section{Distribution of Blood Components}

The frequency distribution of blood samples according to phos-

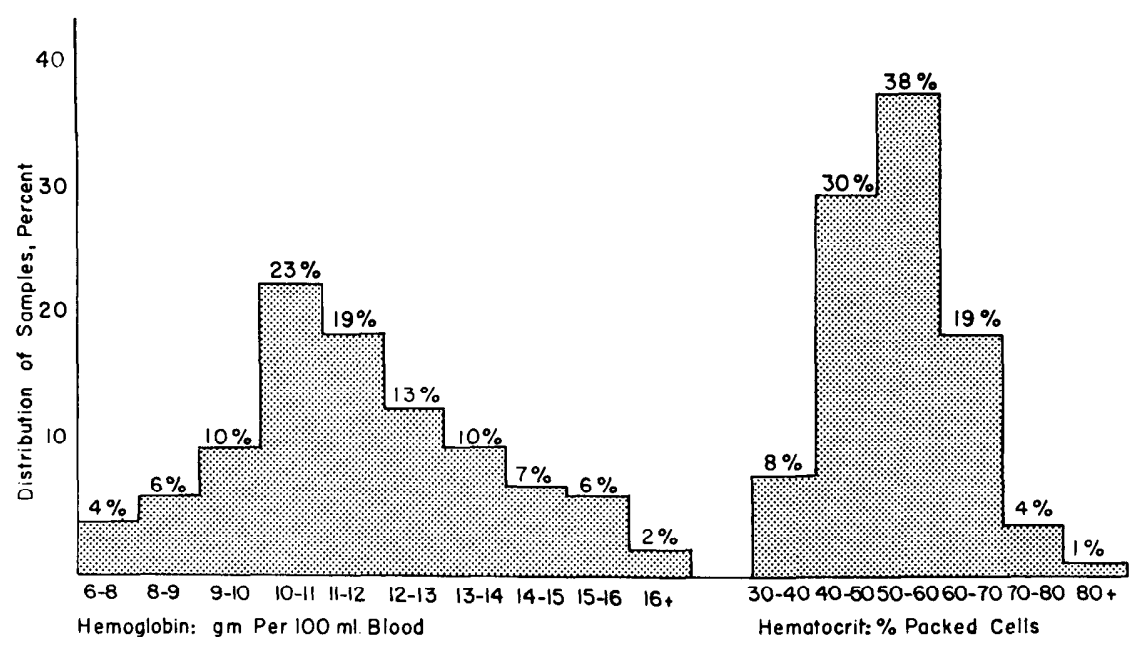

phorus and calcium content are shown in Fig. 1 and on a basis of hemoglobin and hematocrit in Fig. 2. Seventy-nine percent of phosphorus values are between 4 and 7 and $73 \%$ of calcium values between 10 and $13 \mathrm{mg}$ per $100 \mathrm{ml}$ plasma. Seventy-five percent of hemoglobin values are from 9 to $14 \mathrm{gm}$ per 100 $\mathrm{ml}$ blood and $87 \%$ of blood samples have hematocrit values from 40 to $70 \%$.

\section{Summary}

Blood samples from five groups of cows on native range with differing management practices including burning $1 / 2$ the pasture and feeding various winter supplements were analyzed for phosphorus, calcium, hemoglobin, and hematocrit.

Fic. 2. Distribution of hemoglobin and hematocrit in cows blood. 
Adjusted mean values for all blood samples were: phosphorus $5.2 \mathrm{mg}$ and calcium $11.4 \mathrm{mg}$ per $100 \mathrm{ml}$ plasma; hemoglobin 11.6 gm per $100 \mathrm{ml}$ blood; and hematocrit $54 \%$ packed cells.

There was a wide variation in the four blood constituents from period to period for individual animals while average values fell within the normal range except for hematocrit. Seventeen percent of the samples showed values for inorganic blood phosphorus below $4 \mathrm{mg}$ per $100 \mathrm{ml}$, although there were no overt symptoms of phosphorus deficiency. None of the animals consistently remained within the deficiency range.

The variability in individual blood samples from the same animal and for different animals during the same period, suggests that single blood analyses should be used with care in evaluating the phosphorus status of range cattle. It also implies that animals may respond to changes in dietary phosphorus intake and to stress factors such as parturition and nursing more rapidly than generally has been supposed.

Blood calcium, hemoglobin and hematocrit values of Brahman cattle were higher than those for the other three breed groups. The extremely high hematocrit values for some animals suggest an unusual unexplained circumstance but probably not related to treatments.

\section{Literature Cited}

Becker, R. B., P. T. Dix Arnold, W. G. Kirk, George K. Davis, and R. W. KidDER. 1957. Minerals for dairy and beef cattle. Fla. Agr. Exp. Sta. Bull. 513R. 51 p.

Becker, R. B., W. M. Neal, AND A. L. ShEaly. 1933. Stiffs or sweeny (phosphorus deficiency) in cattle. Fla. Agr. Exp. Sta. Bull. 264. 27 p.

Becker, R. B., J. R. Henderson, aNd R. B. Leighty. 1965. Mineral nutrition of cattle. Fla. Agr. Exp. Sta. Tech. Bull. 699. 54 p.

Braun, Werner. 1946. Average levels of various constituents, physical properties and formed elements of the blood of cows on pasture. Amer. J. Vet. Sci. 7:450-454.

Brooks, H. J., and J. S. Hughes. 1932. The hemoglobin content of the blood of dairy cattle. J. Nutr. 5: 35-38.

BudykA, I. K. 1961. Content of calcium and inorganic phosphorus in blood of cattle in relation to age, physiological state and diet. Tr. Orenburgsk. Sel'skokhoz. Inst. 13: 12-18 (Chem. Abstr.).

Clark, E. P., and J. B. Collip. 1925. A study of the Tisdale method for the determination of blood serum calcium with a suggested modification. J. Biol. Chem. 63:461-464.

Cohen, B., And A. H. SMith. 1919. The colorimetric determination of hemoglobin. J. Biol. Chem. 39:489.

Cunha, T. J., R. L. Shirley, H. L. Ghapman, Jr., C. B. Ammerman, G. K. Davis, W. G. Kirk, and J. F. HENTGES. 1964. Minerals for beef cattle in Florida. Fla. Agr. Exp. Sta. Bull. 683. 60 p.

Duncan, D. A., and E. A. Epps, Jr. 1958. Mineral elements and other nutrients on forest ranges in central Louisiana. La. Agr. Exp. Sta. Bull. 516. 19 p.

Duvall, V. L., and S. L. Hansard. 1967. Response of southern range cattle to protein supplementation. J. Range Manage. 20:153-157.

Fiske, C. H., ANd Y. Subbarow. 1925. The colorimetric determination of phosphorus. J. Biol. Chem. 66:375.

Kramer, Clyde Young. 1959. Extension of multiple range test to group correlated adjusted means. Biometrics 13:13-18.

Nutrient Requirements of Beef CatTLE. 1963. National Research Council. Pub. 1137. Washington, D.C. $30 \mathrm{p}$.

Shirley, R. L., J. F. Easley, J. T. McGall, G. K. Davis, W. G. Kirk, AND E. M. Hodges. 1968. Phosphorus fertilization of pangolagrass pasture and phosphorus, calcium, hemoglobin, and hematocrit in blood of cows. J. Anim. Sci. 27:757-765.

\section{Back Issues-JRM}

A number of persons have complete, or nearly complete, sets of the Journal of Range Management which are available for donation to colleges or libraries, either in the United States or abroad. This provides an excellent opportunity for institutions that are building their libraries to acquire a full set of the Journal at little or no cost. If you know of any such institutions, please have them contact the Executive Secretary's office for names and addresses of prospective donors.

Additionally, the two volumes of JRM immediately preceding the current volume (or, presently, Vols. 21 and 22) are available from the Executive Secretary's office at $\$ 15.00$ per volume or $\$ 2.50$ per issue, postpaid.

All other back issues may be purchased from Walter J. Johnson, Inc., 111 Fifth Avenue, New York, N.Y. 10003. Contact this firm directly for details and prices. 